CZASOPISMO INŻYNIERII LA¿DOWEJ, ŚRODOWISKA I ARCHITEKTURY JOURNAL OF CIVIL ENGINEERING, ENVIRONMENT AND ARCHITECTURE JCEEA, t. XXXIII, z. 63 (2/I/16), kwiecień-czerwiec 2016, s. 129-141

\author{
Justyna KWAŚNY ${ }^{1}$ \\ Wojciech BALCERZAK ${ }^{2}$ \\ Piotr REZKA ${ }^{3}$
}

\title{
BIOGAZ I CHARAKTERYSTYKA WYBRANYCH METOD JEGO ODSIARCZANIA
}

\begin{abstract}
W niniejszym artykule w oparciu o dane literaturowe, poruszono kwestie otrzymywania biogazu oraz jego odsiarczania. Biogaz stanowi odnawialne źródło energii, które powstaje w wyniku fermentacji beztlenowej biomasy różnego pochodzenia. W zależności od rodzaju substratów stosowanych w procesie, zmienia się skład chemiczny otrzymywanej mieszaniny gazowej. Należy pamiętać, że pozyskiwany biogaz surowy zawiera tylko średnio $60 \%$ obj. metanu, natomiast pozostałymi składnikami są ditlenek węgla, para wodna, siarkowodór, amoniak, siloksany i inne. Wyróżnia się biogaz wysypiskowy, który otrzymuje się w wyniku przetwarzania nieposegregowanych odpadów komunalnych; biogaz rolniczy, otrzymywany z odpadów rolniczych, a także biogaz pozyskiwany z osadów ściekowych i biogaz powstający w wyniku przetworzenia odpadów z branży przemysłu żywnościowego. Obecność w biogazie surowym substancji gazowych, innych niż metan, obniża jego potencjał energetyczny, a także ogranicza możliwości jego zastosowania. Wspomniane substancje gazowe stanowią zanieczyszczenia, które charakteryzują się niekorzystnym wpływem na środowisko naturalne (gazy cieplarniane) oraz korozyjnością w stosunku do aparatury (głównie siarkowodór). Aby polepszyć właściwości użytkowe biogazu należy przeprowadzić jego odsiarczanie, oczyszczanie i uzdatnianie. Skutkuje to uzyskaniem biogazu o właściwościach gazu ziemnego, który można wtłoczyć do sieci infrastruktury gazowej. Odsiarczanie biogazu polega na usunięciu lub ograniczeniu zawartości siarkowodoru w mieszaninie gazowej. Proces ten może być prowadzony kilkoma metodami. Wśród metod odsiarczania wyróżnia się m.in. utlenianie biologiczne, metody mokre, a także metody sorpcyjne, np. adsorpcję na węglu aktywnym.
\end{abstract}

Słowa kluczowe: biogaz wysypiskowy, adsorbenty, metody biologiczne, usuwanie siarkowodoru, węgiel aktywny, zeolity

\footnotetext{
${ }^{1}$ Autor do korespondencji/corresponding author: Justyna Kwaśny, Wydział Inżynierii Środowiska, Politechnika Krakowska, ul. Warszawska 24, 31-155 Kraków, kwasny.justyna@gmail.com

${ }^{2}$ Wojciech Balcerzak, Instytut Zaopatrzenia w Wodę i Ochrony Środowiska, Wydział Inżynierii Środowiska, Politechnika Krakowska, ul. Warszawska 24, 31-155 Kraków, wb@ vistula.wis.pk.edu.pl

${ }^{3}$ Piotr Rezka, Wydział Inżynierii Środowiska, Politechnika Krakowska, ul. Warszawska 24, 31-155 Kraków, rezkapiotr@gmail.com
} 


\section{Wstęp}

Wraz z rozwojem cywilizacji rośnie zapotrzebowanie na energię, której tradycyjne zasoby nieustannie się wyczerpują. Również powszechnie wiadomo, że stosowanie paliw kopalnianych jest niekorzystne dla środowiska naturalnego. Dlatego też, na znaczeniu zyskują odnawialne źródła energii (OZE), których zasoby stale się uzupełniają. Do grupy tych nośników energii zalicza się promieniowanie słoneczne, wodę, wiatr, źródła geotermalne, a także biomasę [16], z której otrzymuje się biopaliwa stałe, biopaliwa płynne i biogaz. Stosowanie odnawialnych źródeł energii w znacznym stopniu zmniejsza szkodliwy wpływ sektora energetycznego na środowisko naturalne, co jest zauważane przede wszystkim w ograniczeniu emisji zanieczyszczeń, głównie gazów cieplarnianych do atmosfery.

Biogaz powstaje w wyniku fermentacji metanowej biomasy różnego pochodzenia. Surowy biogaz zawiera znaczne ilości zanieczyszczeń, które obniżają jego potencjał energetyczny lub uniemożliwiają jego zastosowanie np. w sieci gazu ziemnego, ze względu na wysoką korozyjność. W celu poszerzenia możliwości aplikacyjnych biogazu przeprowadza się jego odsiarczanie, oczyszczanie i uzdatnianie do jakości gazu ziemnego. Odsiarczanie biogazu polega na usunięciu siarkowodoru, co może odbywać się różnymi metodami, które zostaną omówione w dalszej części referatu.

\section{Charakterystyka biogazu}

Produktem procesu fermentacji beztlenowej jest biogaz, którego głównym składnikiem jest metan, następnie tlenek węgla (IV) i para wodna oraz inne substancje gazowe $[1,23,25,26,29,33]$. W zależności od surowców z jakich jest pozyskiwany wyróżnia się biogaz wysypiskowy, rolniczy, z osadów ściekowych i z odpadów rzeźniczych, browarniczych i innych pochodzących z branży żywnościowej [9,32]. Rodzaj biomasy stanowiącej substraty w procesie fermentacji metanowej determinuje skład chemiczny powstałej mieszaniny, nazywanej często biogazem surowym. Różnice zawartości poszczególnych składników prezentuje tabela 1 . Hernández i współpracownicy [13] analizowali skład chemiczny biogazu wysypiskowego z Turynu, a wyniki jakie otrzymali przedstawiono w tabeli 2 . Biogaz powstający z odpadów gospodarstwa domowego i na wysypiskach odpadów komunalnych (nieposegregowanych) zawiera znaczne ilości związków aromatycznych oraz chlorowco- $\mathrm{i}$ fluoroorganicznych, co wynika z obecności odpadów tworzyw sztucznych we wsadzie fermentacyjnym. Największą zawartością siarkowodoru w biogazie surowym, charakteryzuje się biogaz pochodzenia rolniczego. Natomiast biogaz powstający z przetworzenia odpadów branży żywnościowej wykazuje największą zawartość amoniaku. W przypadku biogazu wysypiskowego problematyczna jest również obecność siloksanów, pół-lotnych związków krzemoorganicznych, które podczas spalania ulegają przemianie do krzemionki. W efekcie może dojść do ścierania części ruchomych silnika itp. [13,27,32]. 
Tabela 1. Skład chemiczny biogazu różnego pochodzenia, opracowano na podstawie [3]

Table 1. The chemical composition of various origins biogas, on the basis of [3]

\begin{tabular}{|c|c|c|c|c|c|}
\hline Składnik & Jednostka & $\begin{array}{c}\text { Odpady } \\
\text { z gospodarst } \\
\text { w domowych }\end{array}$ & $\begin{array}{c}\text { Osad } \\
\text { z oczyszczalni } \\
\text { ścieków }\end{array}$ & $\begin{array}{c}\text { Odpady rolni- } \\
\text { czych }\end{array}$ & \begin{tabular}{|c|} 
Odpady \\
z przemysłu \\
rolno- \\
spożywczego \\
\end{tabular} \\
\hline $\mathrm{CH}_{4}$ & \multirow{4}{*}{$\%$ obj. } & $50-60$ & $60-75$ & $60-75$ & 68 \\
\hline $\mathrm{CO}_{2}$ & & $34-38$ & $19-33$ & $19-33$ & 26 \\
\hline $\mathrm{N}_{2}$ & & $0-5$ & $0-1$ & $0-1$ & - \\
\hline $\mathrm{O}_{2}$ & & $0-1$ & $<0,5$ & $<0,5$ & - \\
\hline $\mathrm{H}_{2} \mathrm{O}$ & $\begin{array}{c}\% \text { obj. } \\
\left(\mathrm{w} 40^{\circ} \mathrm{C}\right)\end{array}$ & 6 & 6 & 6 & 6 \\
\hline $\mathrm{H}_{2} \mathrm{~S}$ & \multirow{4}{*}{$\mathrm{mg} / \mathrm{m}^{3}$} & $100-900$ & $1000-4000$ & $3000-10000$ & 100 \\
\hline $\mathrm{NH}_{3}$ & & - & - & $50-100$ & 400 \\
\hline Związki aromatyczne & & $0-200$ & - & - & - \\
\hline $\begin{array}{l}\text { Związki chlorowco- } \\
\text { organiczne lub } \\
\text { fluoroorganiczne }\end{array}$ & & $100-800$ & - & - & - \\
\hline
\end{tabular}

Tabela 2. Charakterystyka biogazu wysypiskowego

Table 2. Characteristics of landfill biogas

\begin{tabular}{|c|c|c|c|c|c|c|c|c|}
\hline \multirow{2}{*}{ Parametr } & \multirow{2}{*}{\begin{tabular}{|c|} 
Jednostka \\
pomiarowa
\end{tabular}} & \multicolumn{7}{|c|}{ Przedział wartości wg } \\
\hline & & [13] & {$[10]$} & [27] & [20] & [34] & [31] & [2] \\
\hline Temperatura & ${ }^{\circ} \mathrm{C}$ & $9-26$ & $\mathrm{n}-\mathrm{p} * *$ & $n-p$ & $n-p$ & $37,7-48,9$ & $n-p$ & $n-p$ \\
\hline Wilgotność & $\% \mathrm{v}$ & $0,6-1,1$ & $n-p$ & $n-p$ & $n-p$ & $\mathrm{n}-\mathrm{p}$ & $1-5$ & $n-p$ \\
\hline $\mathrm{CH}_{4}$ & $\% \mathrm{v}$ & $42,8-50,2$ & $40,0-70,0$ & $32-58$ & $55-65$ & $45-60$ & $35-65$ & $30-60$ \\
\hline $\mathrm{O}_{2}$ & $\% \mathrm{v}$ & $1,5-2,8$ & $0-5,0$ & $0,33-6$ & $n-p$ & $0,1-1,0$ & 1 & $0-10$ \\
\hline $\mathrm{CO}_{2}$ & $\% \mathrm{v}$ & $34-40,9$ & $30,0-50,0$ & $31-54$ & $40-45$ & $40-60$ & $15-40$ & $15-40$ \\
\hline $\mathrm{CO}$ & $\% \mathrm{v}$ & \begin{tabular}{|c|}
$<0,001-$ \\
0,003 \\
\end{tabular} & $n-p$ & $\begin{array}{c}0,025- \\
0,32 \\
\end{array}$ & $n-p$ & $0,0-0,2$ & $n-p$ & \\
\hline $\mathrm{N}_{2}$ & $\% \mathrm{v}$ & $11,4-16$ & $0-20$ & $1,2-19$ & $\mathrm{n}-\mathrm{p}$ & $2-5$ & 15 & $0-50$ \\
\hline $\mathrm{H}_{2}$ & $\% \mathrm{v}$ & $<0,1$ & $n-p$ & $<0,01$ & $n-p$ & $0,0-0,2$ & $0-3$ & $n-p$ \\
\hline BTEX* & $\operatorname{ppm}_{\mathrm{v}}$ & $n-p$ & $n-p$ & $\begin{array}{l}132-168 \\
\mathrm{mg} / \mathrm{Nm}^{3} \\
\end{array}$ & $\begin{array}{c}28,7- \\
65,4\end{array}$ & $n-p$ & $n-p$ & $n-p$ \\
\hline Siloksany & $\mathrm{mg} / \mathrm{m}^{3}{ }_{\mathrm{N}}$ & $\begin{array}{c}<0,05- \\
0,2 \\
\end{array}$ & $0-100,0$ & $\begin{array}{c}13,8 \\
\mathrm{mg} \mathrm{Si} / \mathrm{Nm}^{3} \\
\end{array}$ & $n-p$ & $n-p$ & $n-p$ & $0-50$ \\
\hline $\begin{array}{l}\text { Lotne związki organ } \\
\text { iczne całkowite }\end{array}$ & $\mathrm{mg} / \mathrm{m}^{3}{ }_{\mathrm{N}}$ & $n-p$ & $n-p$ & $\begin{array}{l}581- \\
1540\end{array}$ & $0,2-4500$ & $n-p$ & $n-p$ & $n-p$ \\
\hline $\mathrm{NH}_{3}$ & $\mathrm{mg} / \mathrm{m}^{3}{ }_{\mathrm{N}}$ & $\begin{array}{c}<0,5- \\
15,7\end{array}$ & $n-p$ & \begin{tabular}{|c|}
$0,022-$ \\
$0,055 \% \mathrm{v}$
\end{tabular} & $n-p$ & $n-p$ & $5 \mathrm{ppm}$ & $0-5$ \\
\hline Chlor całkowity & $\mathrm{mgCl} / \mathrm{m}^{3}{ }_{\mathrm{N}}$ & $\begin{array}{c}17,4- \\
32,0\end{array}$ & $n-p$ & $\begin{array}{l}0,12- \\
21,50\end{array}$ & $n-p$ & $n-p$ & $\begin{array}{c}5 \\
\mathrm{mg} / \mathrm{m}_{\mathrm{N}}^{3} \\
\end{array}$ & \begin{tabular}{|c|}
$0-800$ \\
$\mathrm{mg} / \mathrm{m}^{3}{ }_{\mathrm{N}}$
\end{tabular} \\
\hline Fluor całkowity & $\mathrm{mgF} / \mathrm{m}^{3}{ }_{\mathrm{N}}$ & $1,2<6,6$ & $n-p$ & $n-p$ & $n-p$ & $n-p$ & $n-p$ & $\begin{array}{l}0-800 \\
\mathrm{mg} / \mathrm{m}_{\mathrm{N}}^{3}\end{array}$ \\
\hline $\mathrm{H}_{2} \mathrm{~S}$ & ppm & $\begin{array}{c}114,3- \\
205,0\end{array}$ & $0-4000$ & $77-3400$ & $n-p$ & $n-p$ & $0-100$ & $\begin{array}{l}0-1000 \\
\mathrm{mg} / \mathrm{m}^{3}{ }_{\mathrm{N}}\end{array}$ \\
\hline Merkaptany & ppm & $0,7-27,7$ & $0-100,0$ & $n-p$ & $n-p$ & $n-p$ & $n-p$ & $n-p$ \\
\hline
\end{tabular}

*BTEX - Benzen, toluen, etylobenzen, ksyleny; **n-p - Nie podano 
Na skład chemiczny biogazu surowego, oprócz rodzaju biomasy, wpływa również sposób prowadzenia procesu technologicznego. Istotny wpływ na przebieg procesu fermentacji metanowej ma temperatura, wilgotność, odczyn $\mathrm{pH}$, rodzaj mikroorganizmów, ale również ilość komór fermentacyjnych, sposób dozowania substratów procesu, a także zawartość suchej masy w komorze fermentacyjnej. W tabeli 3 przedstawiono parametry prowadzenia fermentacji beztlenowej.

Tabela 3. Charakterystyka parametrów prowadzenia fermentacji metanowej, opracowano na podstawie $[11,12,19,24,28]$

Table 3. Characteristics of methane fermentation parameters, on the basis of $[11,12,19,24,28]$

\begin{tabular}{|c|c|c|c|c|}
\hline Parametr & \begin{tabular}{|c|} 
Optymal- \\
ne wa- \\
runki \\
procesu
\end{tabular} & $\begin{array}{c}\text { Bakterie ak- } \\
\text { tywne w po- } \\
\text { danym zakre- } \\
\text { sie }\end{array}$ & \begin{tabular}{|c|} 
Warunki \\
najczęściej \\
utrzymy- \\
wane
\end{tabular} & Możliwe utrudnienia \\
\hline \multirow{3}{*}{ Temp. $\left[{ }^{\circ} \mathrm{C}\right]$} & $20-25$ & psychrofilne & \multirow{3}{*}{$30-40$} & \multirow{3}{*}{$\begin{array}{l}\text { W niektórych przypadkach (materiał pocho- } \\
\text { dzenia zwierzęcego - Animal By Product) za- } \\
\text { chodzi konieczność higienizacji, w celu usu- } \\
\text { nięcia bakterii chorobotwórczych - możliwość } \\
\text { fermentacji z użyciem bakterii termofilnych. } \\
\text { Prowadzenie procesu w wyższej temperaturze } \\
\text { sprawia, że jest on bardziej wrażliwy na zakłó- } \\
\text { cenia. Dlatego też, proces higienizacji najczę- } \\
\text { ściej prowadzi się przed fermentacją, poprzez } \\
\text { wygrzewanie substratu w temperaturze min. } \\
70^{\circ} \mathrm{C} \text { przez min. godzinę, przy określonym } \\
\text { rozmiarze cząstek materiału - max } 12 \mathrm{~mm} \text {. }\end{array}$} \\
\hline & $35-37$ & mezofilne & & \\
\hline & $55-60$ & termofilne & & \\
\hline $\begin{array}{l}\text { Zawartość } \\
\text { węgla } \\
\text { i azotu - } \\
\text { stosunek } \\
\text { C/N }\end{array}$ & $10-30$ & $\begin{array}{c}\text { wszystkie ro- } \\
\text { dzaje bakterii } \\
\text { biorące udział } \\
\text { w procesie }\end{array}$ & $10-30$ & $\begin{array}{l}\text { Nadmierna ilość związków azotu w substratach } \\
\text { procesu prowadzi do jego akumulacji w postaci } \\
\mathrm{NH}_{3} \text {, który przy wysokim stężeniu jest tok- } \\
\text { syczny dla bakterii metanogennych. Nadmierna } \\
\text { zawartość węgla skutkuje jego niepełnym wy- } \\
\text { korzystaniem i obecnością w masie pofermen- } \\
\text { tacyjnej. Regulację przeprowadza się za pomo- } \\
\text { cą dodatku odpowiednich kosubstratów. }\end{array}$ \\
\hline \multirow{2}{*}{ Odczyn $\mathrm{pH}$} & $4,5-6,3$ & $\begin{array}{c}\text { hydrolizujące } \\
\text { i kwasotwór- } \\
\text { cze }\end{array}$ & \multirow{2}{*}{$6,5-7,5$} & \multirow{2}{*}{$\begin{array}{l}\text { Obniżenie pH na skutek nadmiernej koncentra- } \\
\text { cji lotnych kwasów tłuszczowych. W przypad- } \\
\text { ku prowadzenia procesu w jednym fermentato- } \\
\text { rze, zachodzi konieczność utrzymywania pH } \\
\text { w wyższym zakresie. }\end{array}$} \\
\hline & $6,8-7,5$ & $\begin{array}{c}\text { acetogenne } \\
\text { i metanogenne }\end{array}$ & & \\
\hline
\end{tabular}

Natomiast charakterystykę kryteriów technologicznych procesu fermentacji zawarto na rysunku 1, gdzie uwzględniono takie czynniki jak temperatura, zawartości suchej masy w komorze fermentacyjnej, a także liczba tych komór, rozdział faz procesu fermentacji oraz sposób dozowania substratów. Wymienione kryteria wpływają na dostępność i żywotność mikroorganizmów odpowiadających za poszczególne etapy fermentacji beztlenowej. 


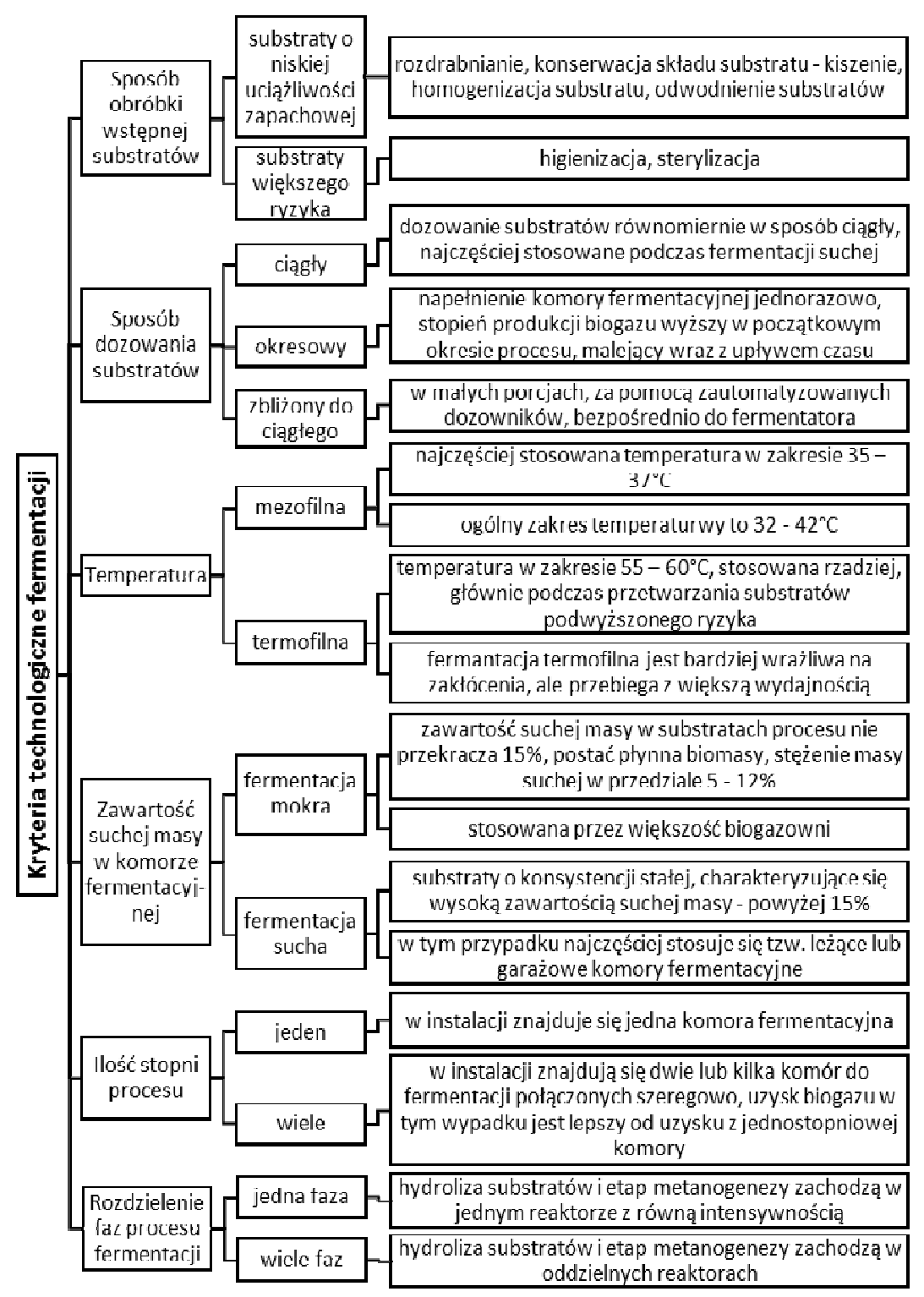

Rys. 1. Charakterystyka kryteriów prowadzenia fermentacji metanowej, opracowano na podstawie $[17,19]$

Fig. 1. Characteristics of methane fermentation criteria, on the basis of $[17,19]$

Skład chemiczny biogazu decyduje o możliwościach jego zastosowania. Obecnie głównym sposobem zużycia biogazu jest jego przetworzenie na ciepło. Według danych Głównego Urzędu Statystycznego [9] w latach 2004-2013 ilość pozyskanego biogazu wzrastała. 
Strukturę zużycia biogazu w 2004 i 2013 roku przedstawiono na rysunku 2. Produkcja tego gazu palnego w 2004 roku wynosiła 1941 TJ, podczas gdy w 2013 wzrosła i wyniosła 7593 TJ. W tym okresie biogaz zużywany był głównie w ciepłowniach i elektrociepłowniach. Natomiast tzw. zużycie finalne, czyli końcowe dotyczy wykorzystania biogazu przez sektor przemysłowy, sektor handlu i usług, a także budownictwo, rolnictwo i leśnictwo.

Zarówno w 2004 jak i 2013 roku głównym kierunkiem spożytkowania biogazu było zużycie na wsad przemian, polegające na przetworzeniu go na inny nośnik energii, co skutkuje ponownym uzyskaniem energii. Wzrost tego kierunku zużycia skutkował zmniejszeniem zużycia finalnego biogazu, w porównaniu z 2004 rokiem. Również nie bez znaczenia jest udział innych OZE w wytwarzaniu energii pierwotnej i jej zużyciu finalnym. Należy podkreślić, że na przestrzeni omawianych lat następował wzrost zużycia finalnego energii pozyskanej z biopaliw stałych, odpadów komunalnych, a także obserwowano wzrost zużycia finalnego energii słonecznej i geotermalnej. Strategicznym celem polityki Polski jest zwiększenie udziału energii ze źródeł odnawialnych w finalnym zużyciu energii brutto, które w roku 2020 powinno osiągnąć poziom 15\%. W roku 2012 udział energii ze źródeł odnawialnych w finalnym zużyciu energii ogółem w Polsce wyniósł 7,2\%. Według Iglińskiego i współpracowników [14] Polska, jako kraj rolniczy dysponuje ogromnym potencjałem biomasy, który może zostać wykorzystany do produkcji biogazu. Może o tym świadczyć fakt, że w ciągu ostatnich 15 lat wybudowano w kraju 250 biogazowni.

Biogaz surowy, jak pokazano w tabelach 1 i 2 zawiera oprócz metanu również inne substancje gazowe, które są uznawane za zanieczyszczenie. Obniżają one potencjał energetyczny biogazu i dodatkowo mają właściwości korozyjne, co ogranicza możliwości jego zużycia [4]. Dlatego też, istotne jest usunięcie z biogazu gazowych zanieczyszczeń, dążąc do uzyskania medium o właściwościach gazu ziemnego.

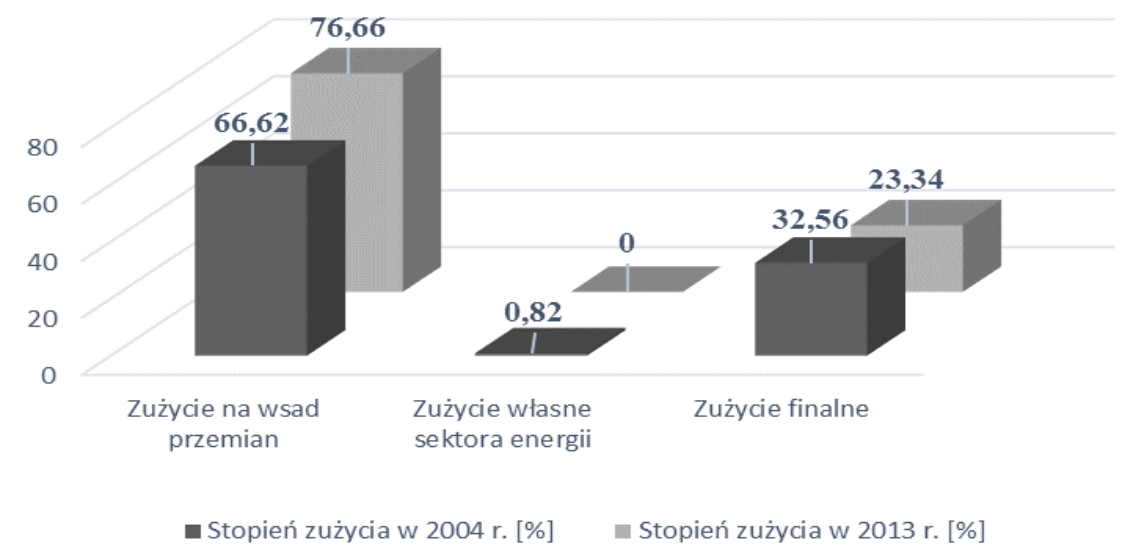

Rys. 2. Struktura zużycia biogazu w 2004 i 2013 roku, opracowano na podstawie [9]

Fig. 2. The structure of biogas consumption in 2004 and 2013 years, on the basis of [9] 


\section{Podział i charakterystyka wybranych metod odsiarczania biogazu}

Odsiarczanie biogazu polega na usunięciu $\mathrm{H}_{2} \mathrm{~S}$ i ewentualnie innych gazowych związków siarki obecnych w mieszaninie. Najczęściej jednak dotyczy to ograniczenia zawartości $\mathrm{H}_{2} \mathrm{~S}$, który oprócz nieprzyjemnego zapachu charakteryzuje się wysoką reaktywnością $\mathrm{z}$ większością metali, np. żelazem, miedzią, przez co powoduje korozję rur przesyłowych i aparatury. Gaz ten ulega przemianie do $\mathrm{SO}_{2} \mathrm{i}_{2} \mathrm{SO}_{4}$, które również mają właściwości wysoko korozyjne, a także są niebezpieczne dla zdrowia i środowiska naturalnego [26].

Wśród metod odsiarczania biogazu wyróżnić można utlenianie biologiczne, techniki adsorpcyjne, zastosowanie złóż rudy darniowej oraz metody mokre [15]. Ich wybór jest zależny od zawartości $\mathrm{H}_{2} \mathrm{~S}$ w biogazie surowym [7].

\subsection{Metody mokre}

Metody mokre polegają na sorpcji $\mathrm{H}_{2} \mathrm{~S}$ w roztworach chemicznych wiążących siarkowodór. Zachodzą poprzez wymywanie $\mathrm{H}_{2} \mathrm{~S}$ z biogazu w płuczkach wieżowych za pomocą odpowiedniej cieczy roboczej. Wśród metod mokrych wyróżnia się metody oparte na adsorpcji fizycznej, które polegają na rozpuszczeniu $\mathrm{H}_{2} \mathrm{~S} w$ wodzie lub rozpuszczalnikach organicznych [2]. Znana jest metoda stosowania, jako ciecz roboczą $\mathrm{CH}_{3} \mathrm{OH}$ w temperaturze od $-20^{\circ} \mathrm{C}$ do $-70^{\circ} \mathrm{C}$, pod ciśnieniem $2-5 \mathrm{MPa}$ (proces Rectisol i Ifpex). Niestety te metody charakteryzują się wysokimi kosztami regeneracji cieczy, dużym jej zużyciem - są nieopłacalne. Natomiast często stosowane są metody mokre oparte na adsorpcji chemicznej, np. w roztworze sody kaustycznej $(\mathrm{NaOH})$, w wodnych roztworach alkanoloamin i w roztworze chlorku żelaza. Stosowanie roztworów $\mathrm{NaOH}$ jest opłacalne w sytuacji, gdy stężenie $\mathrm{H}_{2} \mathrm{~S}$ mieści się w granicach $0,05-1,5 \%$, dla biogazu wytwarzanego w ilości $50-1200 \mathrm{~m}^{3} / \mathrm{h}$. Na skutek odsiarczania z cieczy roboczej powstaje ściek, który należy odprowadzić do oczyszczalni. Stosowanie alkanoloamin skutkuje selektywnym usuwaniem siarkowodoru, w przypadku użycia trietanoloaminy (TEA). Natomiast roztwory MEA - monoetanoloaminy i DEA - dietanoloaminy pozwalają usunąć również ditlenek węgla [15].

\subsection{Stosowanie złóż rudy darniowej}

Ruda darniowa jest to porowata skała osadowa charakteryzująca się brunatnym kolorem. Powstaje z rozpuszczalnych związków żelaza znajdujących się w wodzie przy udziale określonych bakterii. Skała ta najczęściej występuje na obszarach, gdzie wody gruntowe znajdowały się blisko powierzchni gleby, np. na terenach bagiennych. W Polsce ruda występuje m.in. na Mazowszu [35].

Metoda $\mathrm{z}$ zastosowaniem rudy darniowej polega na adsorpcji $\mathrm{H}_{2} \mathrm{~S}$ na zasadowych tlenkach żelaza, w wyniku przepuszczenia biogazu przez złoże. Produktami reakcji jest siarka elementarna oraz siarczki żelaza (II) i (III). Proces opisują poniższe reakcje chemiczne. 


$$
\begin{aligned}
& 2 \mathrm{Fe}_{2}(\mathrm{OH})_{3}+3 \mathrm{H}_{2} \mathrm{~S}=2 \mathrm{FeS}+\mathrm{S}+6 \mathrm{H}_{2} \mathrm{O} \\
& 2 \mathrm{Fe}(\mathrm{OH})_{3}+3 \mathrm{H}_{2} \mathrm{~S}=\mathrm{Fe}_{2} \mathrm{~S}_{3}+6 \mathrm{H}_{2} \mathrm{O}+42,3 \mathrm{~kJ}
\end{aligned}
$$

Regenerację złoża prowadzi się przepuszczając przez nie powietrze $\mathrm{z}$ dodatkiem pary wodnej. Jest to metoda efektywna, gdyż stężenie $\mathrm{H}_{2} \mathrm{~S}$ w oczyszczonym gazie nie przekracza kilku $\mathrm{mg} / \mathrm{dm}^{3}$ [15]. Cybulska i współpracownicy [6] prowadzili odsiarczanie biogazu z zastosowaniem masy odsiarczającej, utworzonej na bazie rudy darniowej. Rudę poddano modyfikacji poprzez dodatek modyfikatora spulchniającego i alkalicznego w ilości odpowiednio 9,1 i 3,4 \% suchej masy. Autorzy badali zmiany skuteczności odsiarczania biogazu w czasie i wykazali, że takie rozwiązanie pozwala na obniżenie stężenia $\mathrm{H}_{2} \mathrm{~S}$ poniżej $200 \mathrm{mg} / \mathrm{m}_{\mathrm{n}}{ }^{3}$. W warunkach badanej oczyszczalni złożę należy wymieniać w odstępach sześciu miesięcy [6].

\subsection{Biologiczne odsiarczanie biogazu}

Jedną z najczęściej stosowanych metod usuwania z biogazu $\mathrm{H}_{2} \mathrm{~S}$ jest utlenianie biologiczne, które polega na dostarczeniu powietrza do biogazu, a następnie przepuszczeniu mieszaniny przez czynną warstwę biologiczną. Efektem działania bakterii z rodziny Thiobacillus jest otrzymanie siarki elementarnej oraz siarczynów. Wydajność usunięcia $\mathrm{H}_{2} \mathrm{~S}$ mieści się w granicach 80-99\% [25], przy czym stężenie siarkowodoru po odsiarczaniu wynosi od $30-150 \mathrm{mg} / \mathrm{m}^{3}$. Metodę charakteryzują niskie koszty inwestycyjne i eksploatacyjne. Zaletą jest brak konieczności wprowadzania do układu dodatkowych substancji chemicznych i możliwość bezobsługowego prowadzenia procesu $[2,7,15,22,26]$. Należy podkreślić, że rodzaj otrzymywanej substancji ściśle zależy od stężenia rozpuszczonego $\mathrm{O}_{2}$ - powstawaniu siarki elementarnej sprzyja ograniczenie dostępu tlenu, przy zwiększonym obciążeniu $\mathrm{H}_{2} \mathrm{~S}$ [26].

\subsection{Adsorpcyjne techniki usuwania siarkowodoru z biogazu}

Adsorpcyjne techniki odsiarczania skutkują wysokim stopniem usunięcia 99\%, jednak w większości przypadków ich stosowanie jest opłacalne dla niższych stężeń $\mathrm{H}_{2} \mathrm{~S}$. Istotą procesu jest przepuszczenie biogazu przez kolumnę filtracyjną wypełnioną adsorbentem. Jako adsorbenty stosuje się adsorbenty węglowe, mineralne i mineralno-węglowe, których podział przedstawiono na rysunku 3.

Węgiel aktywny jest jednym $\mathrm{z}$ najbardziej znanych i uniwersalnych adsorbentów [7], który charakteryzuje się wysoką skutecznością adsorpcji zanieczyszczeń i niskimi kosztami stosowania. Możliwość wielokrotnego użycia i odzyskiwania produktu wpływa na obniżenie kosztów eksploatacyjnych $[2,13]$. Dostępne dane literaturowe [13,21,30] pokazują wyższą skuteczność adsorpcji siarkowodoru na węglu aktywnym w porównaniu z zeolitami, komercyjnymi adsorbentami tlenkowymi i sitami jonowymi, co potwierdzają wyniki uzyskane przez Sisani i współpracowników [30], przedstawione na rysunku 4. 


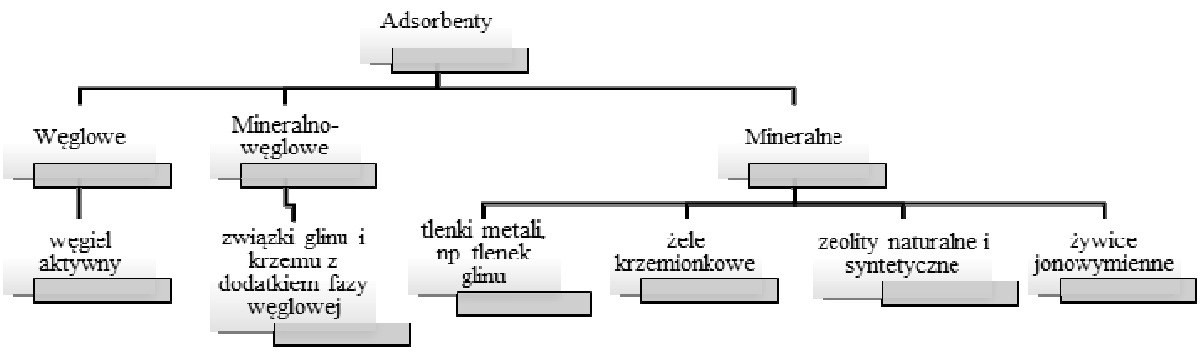

Rys. 3. Rodzaje adsorbentów do odsiarczania biogazu, opracowano na podstawie $[13,18,35]$

Fig. 3. The types of biogas desulfurization adsorbents, on the basis of $[13,18,35]$

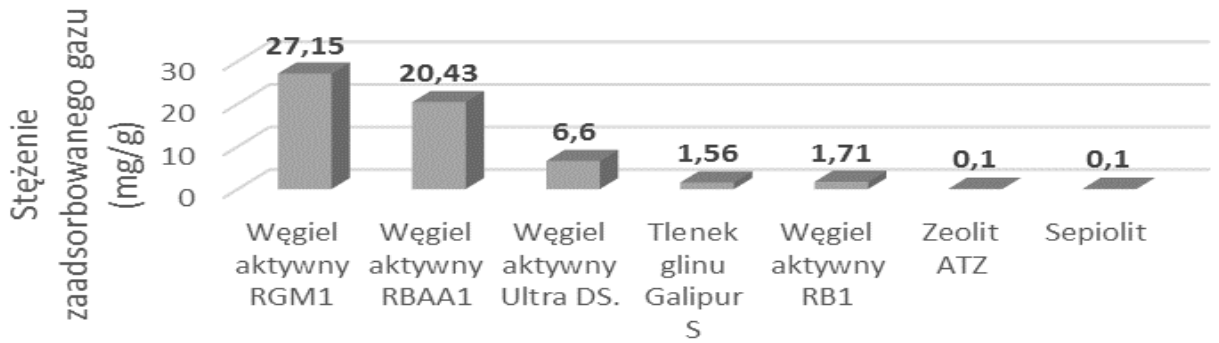

Rys. 4. Porównanie skuteczności adsorpcji siarkowodoru z biogazu, opracowano na podstawie [30]

Fig. 4. Comparison of efficacy of hydrogen sulphide from biogas adsorption, on the basis of [30]

Sisani i współpracownicy [30] prowadzili adsorpcję w temperaturze $30^{\circ} \mathrm{C}$ i wykazali zupełną nieprzydatność zeolitu ATZ i sepiolitu w tym procesie.

Natomiast badania Micoli i współpracowników [21] pokazały, że skuteczność odsiarczania z zastosowaniem zeolitów może być znacznie poprawiona, poprzez modyfikację chemiczną ich struktury. Dokonuje się tego na drodze wymiany jonowej lub impregnacji.

Autorzy w procesie usuwania $\mathrm{H}_{2} \mathrm{~S}$ stosowali modyfikowane na drodze wymiany jonowej (Ex) oraz impregnowane jonami miedzi (Im-Cu) i cynku (Im-Zn) zeolity, a także impregnowane roztworami $\mathrm{Na}_{2} \mathrm{CO}_{3}, \mathrm{KOH}$ i $\mathrm{NaOH}$ węgle aktywne $(\mathrm{AC})$.

Wyniki, jakie uzyskali przedstawiono na rysunku 5.

Najwyższą wydajność adsorpcji $\mathrm{H}_{2} \mathrm{~S}$ uzyskano dla $\mathrm{AC}$ impregnowanego roztworem $\mathrm{Na}_{2} \mathrm{CO}_{3}$.

Należy podkreślić, że niezależnie od impregnacji, węgiel aktywny okazał się być bardziej skuteczny niż badane adsorbenty zeolitowe.

Na uwagę zasługuje fakt znacznego zwiększenia wydajności odsiarczania po przeprowadzeniu modyfikacji struktury zeolitów na drodze wymiany jonowej jonami $\mathrm{Cu}^{2+}$. 
Uzyskane przez Micoli i współpracowników [21] wyniki potwierdziły słuszność tezy, mówiącej, że modyfikacja struktury prowadzi do zwiększenia skuteczności odsiarczania biogazu.

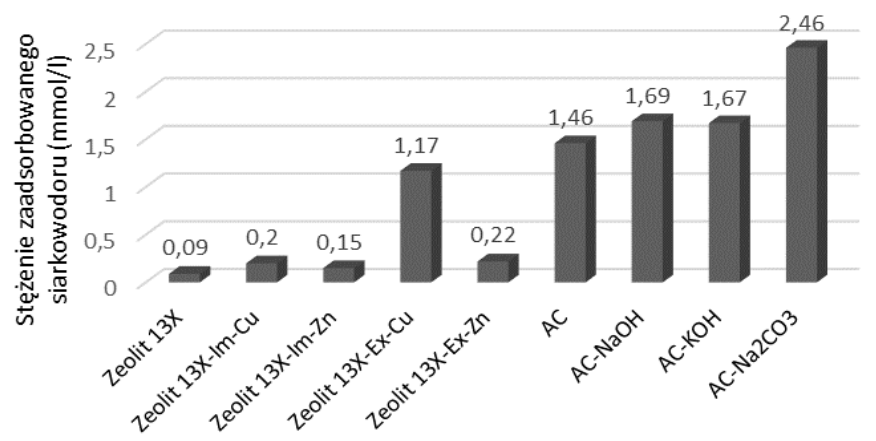

Rys. 5. Porównanie skuteczności adsorbentów zeolitowych i węgla aktywnego w odsiarczaniu biogazu, opracowano na podstawie [21]

Fig. 5. Comparison of efficacy of zeolite adsorbents and activated carbon in biogas desulfurization, on the basis of [21]

\section{Podsumowanie}

W ostatnim czasie ilość biogazu pozyskiwanego z biomasy na drodze fermentacji metanowej systematycznie rosła. Głównym sposobem spożytkowania biogazu jest stosowanie go, jako wsadu w elektrociepłowniach i ciepłowniach. Niestety ze względu na skład chemiczny biogazu surowego, możliwości jego zastosowania są ściśle ograniczone. Za niekorzystny wpływ na środowisko naturalne, obniżenie potencjału energetycznego mieszaniny oraz zwiększenie jej korozyjności odpowiadają gazy, takie jak siarkowodór. Należy ograniczać zawartość tych zanieczyszczeń, w celu poprawienia właściwości użytkowych biogazu. Dlatego też, przeprowadza się jego odsiarczanie, które polega na zmniejszeniu zawartości lub usunięciu siarkowodoru z mieszaniny gazowej. Wyróżnia się kilka metod odsiarczania biogazu, takich jak metody mokre, biologicznego utleniania oraz szereg technik sorpcyjnych. Najwyższym stopniem usunięcia siarkowodoru (do 99,5\%) charakteryzują się metody biologiczne. Również techniki adsorpcyjne skutkują wysoką wydajnością odsiarczania, zwłaszcza przy stosowaniu adsorbentów węglowych. Jednak w przypadku użycia adsorbentów, istotne jest ustalenie maksymalnego stężenia $\mathrm{H}_{2} \mathrm{~S}$, przy którym proces odsiarczania jest opłacalny. Warto również przeprowadzać modyfikację struktury adsorbentów, gdyż skutkuje to polepszeniem właściwości adsorpcyjnych, a w efekcie prowadzi do zwiększenia wydajności procesu odsiarczania. 


\section{Literatura}

[1] Bancer D., Czechowska-Kosacka A., Kosacki R.; Biogazownie źródłem paliw alternatywnych, Czasopismo Inżynierii Lądowej, Środowiska i Architektury, XXXII, 62 (1/15), 2015, 5-12, DOI: 10.7862/rb.2015.1.

[2] Biogas cleaning, Petersson A., in The biogas hand book, edited by Wellinger A., Murphy J.P., Baxter D., Woodhead Publishing Limited, 2013, DOI: 10.1533/9780857097415.3.329.

[3] Biogas composition, Biogas renewable energy - Information webside on biogas, dostęp online http://www.biogas-renewable-energy.info/ \{dostęp 17.10.2015 r.\}

[4] Budzianowski W.M.; A review of potential innovations for production, conditioning and utilization of biogas with multiple-criteria assessment, Renewable and Sustainable Energy Reviews 54, 2016, 1148-1171.

[5] Choma J., Osuchowski Ł., Jaroniec M.; Właściwości i zastosowanie węgli aktywnych otrzymanych z minerałów polimerowych, Ochrona Środowiska 36, 2, 2014, 3-16.

[6] Cybulska H., Gaj K., Knop F., Steininger M.; Badania sorpcji siarkowodoru zawartego w biogazie na uaktywnionej rudzie darniowej, w Aktualne problemy w ochronie powietrza atmosferycznego pod red. Musialik-Piotrowska A., Rutkowski J.D.; Materiały z IX konferencji "POL-EMIS 2008", Karpacz 18-21 czerwca 2008 r. ISBN 978-83-921167-6-9, wyd. PZITS nr 880.

[7] de Arespacochaga N., Valderrama C., Mesa C., Bouchy L., Cortina J.L.; Biogas deep clean-up based on adsorption technologies for Solid Oxide Fuel Cell applications, Chemical Engineering Journal 255, 2014, 593-603.

[8] de Arespacochaga N., Valderrama C., Raich-Montiu J., Crest M., Mehta S., Cortina J.L.; Understanding the effects of the origin, occurrence, monitoring, control, fate and removal of siloxanes on the energetic valorization of sewage biogas - A review, Renewable and Sustainable Energy Reviews 52, 2015, 366-381.

[9] Energia ze źródeł odnawialnych w 2013 r., Główny Urząd Statystyczny, Warszawa 2014, ISSN: 1898- 4347.

[10] Fängmark IE, Hammarström LG, Strömqvist M.E., Ness A.L., Norman P.R., Osmond N.M.; Estimation of activated carbon adsorption efficiency for organic vapours I. A strategy for selecting test compounds, Carbon 40, 2002, 2861-2869.

[11] Głaszka A., Wardal W. J., Romaniuk W., Domasiewicz T., Biogazownie rolnicze, Monografia, MULTICO Oficyna Wydawnicza, Warszawa 2010.

[12] Hamawand I.; Anaerobic digestion process and bio-energy in meat industry: A review and a potential, Renewable and Sustainable Energy Reviews 44, 2015, 37-51.

[13] Hernández S.P., Scarpa F., Fino D., Conti R.; Biogas purification for MCFC application, International Journal of Hydrogen Energy 36, 13, 2011, 8112-8118.

[14] Igliński B., Buczkowski R., Cichosz M.; Biogas production in Poland - Current state, potential and perspectives, Renewable and Sustainable Energy Reviews 50, 2015, 686-695.

[15] Jędrczak A., Biologiczne przetwarzanie odpadów, Wyd. PWN, Warszawa 2007, 186-190, ISBN 978-83-01-15166-9. 
[16] Kalda G., Fornagiel A.; Ochrona środowiska i racjonalne zużycie energii, Czasopismo Inżynierii Lądowej, Środowiska i Architektury, XXXI, 61 (1/14), 2014, 67-84, DOI:10.7862/rb.2014.5.

[17] Kujawski O.; Przegląd technologii produkcji biogazu cz. I, Czysta Energia 12, 2009, dostęp online http://www.cire.pl/pliki/2/TechnologieKujawski1.pdf. \{dostęp 17.10.2015 r.\}

[18] Kwaśny J., Balcerzak W.; Characteristics of selected indirect methods of reducing the emission of odors, Archives of Waste Management and Environmental Protection, 16, 4, 2014, 125-134.

[19] Kwaśny J., Banach M., Kowalski Z., Przegląd technologii produkcji biogazu różnego pochodzenia, Czasopismo Techniczne seria Chemia, 2-Ch, 2012, 17, 109, 83-102, ISSN 0011-4561.

[20] Lakhouit A., Schirmer W.N., Johnson T.R., Cabana A., Cabral A.R.; Evaluation of the efficiency of an experimental biocover to reduce BTEX emissions from landfill biogas, Chemosphere 97, 2014, 98-101.

[21] Micoli L., Bagnasco G., Turco M., H2S removal from biogas for fuelling MCFCs: New adsorbing materials, International Journal of Hydrogen Energy 39, 2014, 1783-1787.

[22] Nemati M., Harrison S.T.L., Hansford G.S. ,Webb C.; Biological oxidation of ferrous sulphate by Thiobacillus ferrooxidans: a review on the kinetic aspects, Biochemical Engineering Journal, 1, 1998, 171-190.

[23] Piwowar A., Dzikuć M., Adamczyk J.; Agricultural biogas plants in Poland - selected technological, market and environmental aspects, Renewable and Sustainable Energy Reviews 58, 2016, 69-74.

[24] Pozyskiwanie i energetyczne wykorzystanie biogazu rolniczego, pod red. Głodek E., Wyd. Instytut Śląski, Opole 2007.

[25] Ramos I., Fdz-Polanco M.; Microaerobic control of biogas sulphide content during sewage sludge digestion by using biogas production and hydrogen sulphide concentration, Chemical Engineering Journal 250, 2014, 303-311.

[26] Ramos I., Pérez R., Reinoso M., Torio R., Fdz-Polanco M.; Microaerobic digestion of sewage sludge on an industrial-pilot scale: The efficiency of biogas desulphurisation under different configurations and the impact of $\mathrm{O}_{2}$ on the microbial communities, Bioresource Technology 164, 2014, 338-346.

[27] Rey M.D., Font R., Aracil I.; Biogas from MSW landfill: Composition and determination of chlorine content with the AOX (adsorbable organically bound halogens) technique, Energy 63, 2013, 161-167.

[28] Rozporządzenie Parlamentu Europejskiego i Rady (WE) nr 1069/2009 z dnia 21 października 2009 r. określające przepisy sanitarne dotyczące produktów ubocznych pochodzenia zwierzęcego, nieprzeznaczonych do spożycia przez ludzi, i uchylające rozporządzenie (WE) nr 1774/2002.

[29] Sheets J.P., Ge X., Li Y.-F., Yu Z., Li Y.; Biological conversion of biogas to methanol using methanotrophs isolated from solid-state anaerobic digestate, Bioresource Technology 201, 2016, 50-57.

[30] Sisani E. et al.; Adsorptive removal of H2S in biogas conditions for high temperature fuel cell systems, International Journal of Hydrogen Energy 39, 2014, 21753-21766. 
[31] Sun Q. et al.; Selection of appropriate biogas upgrading technology-a review of biogas cleaning, upgrading and utilization, Renewable and Sustainable Energy Reviews 51, 2015, 521-532.

[32] Surita S.C., Tansel B.; Preliminary investigation to characterize deposits forming during combustion of biogas from anaerobic digesters and landfills, Renewable Energy 80, 2015, 674-681.

[33] Verriele M., Allam N., Depelchin L., Le Coq L., Locoge N.; Improvement in 8hsampling rate assessment considering meteorological parameters variability for biogas VOC passive measurements in the surroundings of a French landfill, Talanta 144, 2015, 294-302.

[34] Xydis G., Nanaki E., Koroneos C.; Exergy analysis of biogas production from a municipal solid waste landfill, Sustainable Energy Technologies and Assessments 4, 2013, 20-28.

[35] Żarczyński A., Rosiak K., Anielak P., Wolf W.; Praktyczne metody odsiarczania biogazu z siarkowodoru. Cz. 1. Zastosowanie sorbentów stałych, Acta Innovations 12, 2014, 24 - 34, ISSN 2300-5599.

\section{BIOGAS AND CHARACTERISTICS OF ITS SELECTED DESULPHURIZATION METHODS}

\section{S u m m a r y}

In this article, based on the literature, the issues of obtaining biogas and its desulphurization were discussed. Biogas is a renewable source of energy that is produced by anaerobic fermentation of various origins biomass. Depending on the type of feedstock used in the process, chemical composition of obtained gas mixture is changed. Must be remembered that sourced raw biogas contains only an average of $60 \%$ vol. methane and other ingredients are $\mathrm{CO}_{2}$, water vapor, hydrogen sulfide, $\mathrm{NH}_{3}$, siloxanes and others. Biogas is divided into landfill biogas, agricultural biogas, biogas extracted from sewage sludge and biogas which is produced by processing waste from the food industry. The presence of gases other than methane in the raw biogas, reduce its potential energy and limits possibility of its application. These gaseous substances are the impurities which have a negative impact on the environment $\left(\mathrm{CO}_{2}\right)$ and are corrosive with respect to the apparatus (mainly $\mathrm{H}_{2} \mathrm{~S}$ ). To improve the performance of the biogas its desulfurization, purification and treatment should be carried out. The obtained biogas has properties as natural gas and can be pumped into the gas infrastructure network. Desulfurization of biogas involves removing or reducing the amount of hydrogen sulfide in the gas mixture. Desulphurization methods can be divided into biological oxidation, wet methods and the adsorption method.

Keywords: landfill biogas, adsorbents, biological methods, removal of hydrogen sulfide, activated carbon, zeolites

Przestano do redakcji: $30.10 .2015 \mathrm{r}$.

Przyjęto do druku: 1.03.2016 r.

DOI: $10.7862 /$ rb.2016.116 
